\title{
Determinants of Islamic Banking Vulnerability in Indonesia from 2014 to 2020
}

\author{
Muhammad Iqbal ${ }^{1 *}$, Sunaryati ${ }^{2}$, Hadri Kusuma ${ }^{3}$ \\ ${ }^{1}$ Faculty of Islamic Economics and Business, State Islamic University (UIN) Raden Intan \\ Lampung, Indonesia \\ ${ }^{2}$ Faculty of Islamic Economics and Business, State Islamic University (UIN) Sunan \\ Kalijaga Yogyakarta, Indonesia \\ ${ }^{3}$ Faculty Business and Economics, Islamic University of Indonesia, Indonesia
}

Submitted: 30 August, 2021; Accepted: 10 January, 2022; Published: 17 January, 2022

\begin{abstract}
This study aims to analyze the effect of financial performance and macro-economic on Islamic banks' vulnerability in Indonesia from 2014 to 2020. Data were analyzed using the Autoregressive Distributed Lag since their several variables in the economy are dynamic. The results showed that exchange rates and financing are the dominant factors that affect the Islamic banks' vulnerability. Therefore, policymakers tend to identify financial instability and try to avoid the crisis if detected. The Z-score variable in the previous periods (VUL) is another factor that affects Islamic banks' vulnerability.
\end{abstract}

Keywords: autoregressive distributed lag (ARDL), vulnerability, Islamic banking, and Indonesia 


\section{INTRODUCTION}

Banks as intermediary institutions still have several problems including the failure to manage or regulate operational activities that lead to bankruptcy. Therefore, the issue of bankruptcy needs to be examined because the latest threatening case hit Bank Muamalat Indonesia. In 2015, this issue was triggered by the Non-Performing Financing which reached $7.11 \%$ with a nominal value of IDR 2.89 trillion exceeding the maximum limit of $5 \%$. Also, in 2017, financial difficulties occurred in the West Java Syariah Bank with an NPF of $19.2 \%$ and a loss of IDR 383 billion. In the same year, Panin Bank experience vulnerabilities and suffered a considerable loss of IDR 968 billion because its NPF reached 12.5\% (Statistik Perbankan Syariah, 2021). Meanwhile, the failure of many Islamic commercial banks tends to have a domino effect on others. The following are statistics on the development of Indonesian Islamic Banking.

Table 1. Development of Islamic Banking in Indonesia

\begin{tabular}{ccc}
\hline Year & Number of Banks & Number of Bank Offices \\
\hline 2013 & 11 & 1,987 \\
2014 & 12 & 2,163 \\
2015 & 12 & 1,990 \\
2016 & 13 & 1,869 \\
2017 & 13 & 1,825 \\
2018 & 14 & 1,875 \\
2019 & 14 & 1,919 \\
2020 & 14 & 2,042 \\
\hline
\end{tabular}

Source: OJK, 2021

The development of Indonesia's Islamic banking is relatively good despite being showing a slow trend. Table 1 indicates that there were 14 banks and 1,919 offices in December 2019. From 2013 to 2019, these financial institutions increase from 11 to 14 but their existing offices decrease. However, the bank offices reduce to 244 units in 2019 because it was 2,163 in 2014. The development of Islamic banks can also be indicated through bank profitability which one of its indicators is a Return on Assets. The following is the development of Islamic Banks' profitability in Indonesia.

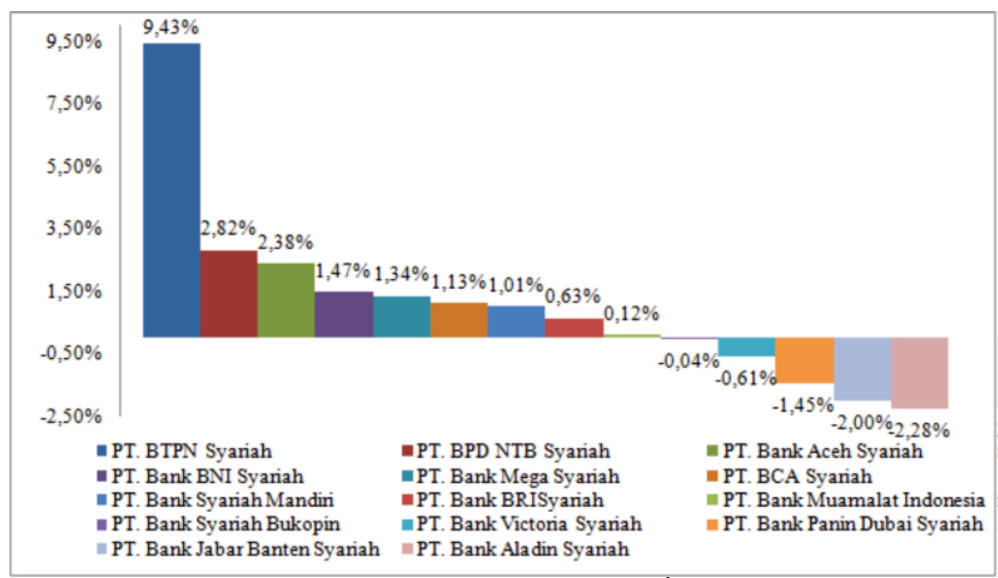

Figure 1. Average Profitability of Islamic Banks in 2015-2020 
Figure 1 shows that only 3 out of 14 Islamic banks have an average ROA of more than $2 \%$ in 2015-2020. This means that these financial institutions in Indonesia failed to create minimum profits. Therefore, this is a problem for the banks because the ratio above does not meet the required $\mathrm{ROA}$.

This study assesses financial instability using the Z-Score that is obtained from the comparison of Return on Assets plus Equity to Total Assets Ratio with standard deviation. The increase in the bank Z-Score leads to the reduction of bankruptcy (Khasawneh, 2016). According to Harzevili and Chirani (2016), a healthy and profitable system play an essential role in financial stability because it is resilient to economic shocks.

Vulnerability is an internal factors condition that leads to or causes the inability of facing a threat. Therefore, economic instability illustrates a level of financial fragility while battling with a danger. According to Bernanke (2013), a shock is a specific event that triggers the occurrence of a crisis or the proximate culture. Therefore, vulnerabilities including external and internal factors tend to increase credit, market, and liquidity risk because they disrupt Indonesian financial stability.

According to Rashid, Yousaf, and Khaleequzzaman (2017), Islamic banks in Pakistan perform better than conventional ones due to their effective contribution to economic durability. The study of Beck, Demirgüç-Kunt and Merrouche (2013) also Mirza, Rahat, and Reddy (2015) showed that there are no significant differences between the two financial institutions. Furthermore, Islamic banks have more asset quality and economic durability than conventional ones. According to Pambuko, Ichsan, and Anto (2018), Islamic banks have lower stability than conventional.

The study of Ghenimi, Chaibi, and Omri (2017) showed that there is no reciprocal relationship between credit and liquidity risk. However, these two risks separately affect bank stability in the Middle East and North Africa region. Trabelsi and Trad (2017) showed that the inflation rate influences financial durability and credit risk. Also, economic growth affects bank profitability, stability and minimizes credit risk. According to Fakhri and Khemaies (2017), capital ratios strengthen the Islamic and conventional banks' stability. Therefore, there is a negative effect of the corruption index on financial durability. The liquidity and credit risk hurts the conventional bank's stability but failed to affect the Islamic one.

According to Al-Khouri and Arouri (2016), the variable board size positively affects the Gulf State banks stability. Meanwhile, government ownership, non-performing loan, a fund to deposit, debt ratio, and regulation positively and insignificantly influences financial durability, while organizational size, concentration, and inflation negatively affect it. The 
results showed that banks became less stable in times of high credit growth. According to Khasawneh's (2016), Islamic banks are profitable but the conventional ones are more stable in the Middle East and North Africa region. These results indicated that internal bank, macroeconomic variables, and financial crisis influence bank profitability and stability.

The internal and external factors cause the rise and fall of the Indonesian banking system. Meanwhile, the internal indicator or fundamental factors is originated and controlled by the management, while the external or non-fundamental is caused by economic conditions including interest rates and government policies (Ali, Sohail, Khan, \& Puah, 2019). The fundamental factors include Non-Performing Financing, Liquidity Risk, Financing, and Bank Size. Furthermore, the macroeconomic indicators that affect bank performance comprise interest and exchange rates, inflation, and economic growth. Previous studies identified eventbased to wait for the occurrence of the banking crisis (Ali \& Puah, 2019; Fakhri \& Khemaies, 2017). According to Pambuko et al., (2018), bank vulnerability measures the aggregate potential for crises in aggregate. This study estimates and identifies the financial instability without examining the factors that trigger the crisis. Therefore, further study is needed to analyze the internal and external indicators that influence Islamic banks' vulnerability in Indonesia. This study aims to analyze the effect of financial performance and macroeconomic on Islamic banks' vulnerability.

\section{Financial System Stability Theory}

Financial stability is the absence of instability that is an economic activity disrupted due to large fluctuations in assets price (Crockett, 1996). The study of Bundesbank (2003) described this economic durability as a balanced state of the financial system. This stability functions efficiently in resource allocation because it manages risks, performs the payment function, and overcomes economic shocks, bankruptcy, as well as fundamental structural changes. The study of Chant (2003) showed that circumstances disrupt financial institution functions and operations.

Meanwhile, financial instability occurs while there is a shock to the economy due to information flow problems. The study of Mishkin (1999) showed that the banking system failed to perform its function of channeling funds into productive investments. Schinasi (2007) defines financial stability as the absence of a crisis because it is a situation where the economy is resilient to shocks. Therefore, the intermediation function, payment system, and risk distribution function are correct. According to Simorangkir (2014), economic resilience includes financial, operational, technological weakness, legal, reputation, strategic, construction, and capital risk. 


\section{The Banking Vulnerability}

The banking vulnerability on the liability side uses the Prisoner's Dilemma theory because the loss of public trust in financial institutions causes simultaneous and instantaneous withdrawals of funds. Also, the behavioral mechanisms were investigated by Diamond and Dybvig (1983). Bank vulnerabilities occur because of the interaction between liquid liabilities and illiquid assets that usually exist for short and long-term respectively.

According to Rusydiana, Rani, and Hasib (2019), banks are easily affected by external factors because they are part of the financing system. Furthermore, banking shakes directly because (1) the cash price is minimal compared to its immediate obligations, (2) the bank's capital is deficient compared to its liabilities, and (3) the short-term financing is substantial. According to Kaufmann, Kraay, and Mastruzzi (2013), vulnerability is a characteristic element that amplifies and propagates the initial shock to magnify financial system wonder.

\section{METHOD}

Data were collected through the secondary results obtained from the Sharia Banking Statistics by The Financial Services Authority. Data were amassed each month between June 2014 and December 2020. Meanwhile, interest, inflation, and exchange rate were obtained from Indonesian Bank, while economic growth was obtained from the Indonesia Central Bureau of Statistics(BPS).

In this study, vulnerability is regarded as the dependent variable because its measuring instrument which consists of 3 components was used by Demirgüç-Kunt, Detragiache, and Tressel, (2008) and Čihák and Hesse (2010). Instability is measured using the Z-Score that is a reflection of bank strength because it assesses the financial failure probability. The following formula is used to calculate the Z-Score.

$$
Z-\text { score }=\frac{R o A+E T A}{\sigma R o A}
$$

Description:

$$
\begin{array}{ll}
\text { RoA } & =\text { Return on Assets } \\
\text { ETA } & =\text { Equity to Total Assets Ratio } \\
\sigma \text { RoA } & =\text { Standard Deviation RoA }
\end{array}
$$

According to Khasawneh (2016), the increase in the Z-Score value tends to reduce the bank's probability of experiencing failure because it indicates the vulnerability level. In this study, the independent variables consist of internal and external factors. Meanwhile, the fundamental indicator includes Non-Performing Financing, Liquidity Risk, Financing and 
Bank Size, while the non-fundamental indicator comprises Interest and Exchange Rates, Inflation, as well as Economic Growth. The following table shows the description of the variables.

Table 2. Research Variables

\begin{tabular}{|c|c|c|c|}
\hline Variable & \multicolumn{2}{|c|}{ Definition } & Source \\
\hline VUL & \multicolumn{2}{|c|}{$\begin{array}{l}\text { Vulnerability banking namely the Z } \\
\text { Score of Islamic Banks }\end{array}$} & h, 2016) \\
\hline NPF & \multicolumn{2}{|c|}{$\begin{array}{l}\text { Ratio Non-Performing Financing of } \\
\text { Islamic Banks }\end{array}$} & $\begin{array}{l}\text { (Ghenimi et al., } 2017 \text { and Trabelsi \& } \\
\text { Trad, 2017) }\end{array}$ \\
\hline LIK & \multicolumn{2}{|c|}{ Liquidity Ratio of Islamic Banks } & $\begin{array}{l}\text { (Khasawneh, 2016; Ali et al., 2019; } \\
\text { and Ali and Puah, 2018) }\end{array}$ \\
\hline LFIN & $\begin{array}{l}\text { garithm of } \\
\text { Banks }\end{array}$ & $\mathrm{F}$ & $\begin{array}{l}\text { (Ali et al., } 2019 \text { and Ali and Puah, } \\
\text { 2018) }\end{array}$ \\
\hline LSIZE & $\begin{array}{l}\text { The logarithm of } \\
\text { Islamic Banks }\end{array}$ & s & $\begin{array}{l}\text { (Khasawneh, } 2016 \text { and Rashid et al., } \\
\text { 2017) }\end{array}$ \\
\hline RATE & \multicolumn{2}{|c|}{$\begin{array}{l}\text { The interest rate of the Indonesian } \\
\text { Bank }\end{array}$} & $\begin{array}{l}\text { (Khasawneh, } 2016 \text {; Srairi, } 2013 \text {; } \\
\text { Rajhi and Hassairi, 2013) }\end{array}$ \\
\hline INF & \multicolumn{2}{|c|}{ Change in a consumer price index } & $\begin{array}{l}\text { (Ghenimi et al ., } 2017 \text { and Ozili, } \\
\text { 2018); }\end{array}$ \\
\hline USD & \multicolumn{2}{|c|}{ IDR: USD at time $t$} & $\begin{array}{l}\text { (Srairi, } 2013 \text {; Rajhi and Hassairi, } \\
\text { 2013); }\end{array}$ \\
\hline GROWTH & \multicolumn{2}{|c|}{$\begin{array}{l}\text { Economic growt h, Interpolation of } \\
\text { quarterly data. }\end{array}$} & $\begin{array}{l}\text { (Ali \& Puah, } 2018 \text {; Khasawneh, } \\
2016 \text {; Trad, Rachdi, Hakimi, and } \\
\text { Guesmi, 2017) }\end{array}$ \\
\hline
\end{tabular}

\section{Method of Data Analysis}

\section{Test Autoregressive Distributed Lag (ARDL)}

ARDL is a combination of Autoregressive and Distributed Lag methods. Meanwhile, the Lag is used to see future values, while the AR uses one or more past data from the variable. The Distributed Lag is a regression method that involves data on the present and past times. According to Gujarati (2011), the ARDL has several advantages including (1) it is different from the Vector Autoregression (VAR) and Vector Error Correction Model (VECM) that require stationary of the same order, and (2) ARDL is not concerned with small samples or observations. Therefore, this study uses the specification of the Autoregressive Distributed Lag method. The following equation defines the dynamic model equation.

$$
\begin{aligned}
\Delta V U L_{t}= & \beta+\beta_{1} \sum_{t-i}^{p} \Delta V U L_{t-i}+\beta_{2} \sum_{t-i}^{p} \Delta N P F_{t-i}+\beta_{4} \sum_{t-i}^{p} \Delta L F I N_{t-i} \\
& +\beta_{5} \sum_{t-i}^{p} \Delta L S I Z E_{t-i}+\beta_{6} \sum_{t-i}^{p} \Delta R A T E_{t-i}+\beta_{7} \sum_{t-i}^{p} \Delta I N F_{t-i} \\
& +\beta_{8} \sum_{t-i}^{p} \Delta U S D_{t-i}+\beta_{9} \sum_{t-i}^{p} \Delta G R O W T H_{t-i}+\beta_{10} N P F_{t-i}+\beta_{11} L I K_{t-i} \\
& +\beta_{12} L F I N_{t-i}+\beta_{13} L S I Z E_{t-i}+\beta_{14} R A T E_{t-i}+\beta_{15} I N F_{t-i} \\
& +\beta_{16} U_{S D_{t-i}}+\beta_{17} G \text { ROWTH } H_{t-i}+\varepsilon_{t}
\end{aligned}
$$

The Autoregressive Distributed Lag (ARDL) method has two advantages including unbiased and efficient because it is used with a small sample. This model enables the long and short-term estimates to be obtained simultaneously to avoid autocorrelation problems. However, it is only a few studies examined the influence of banks' vulnerability using the autoregressive distributed lag method. 


\section{RESULT AND DISCUSSION}

Table 3 shows the stationarity using the PP test (Phillips-Perron). The results indicated that all data are stationary.

Table 3. Stationarity Test

\begin{tabular}{llccc}
\hline No & Variable & $\begin{array}{c}\text { PP(Phillips-Perron) } \\
\text { At Level } \\
\text { Prob. }\end{array}$ & $\begin{array}{c}1^{\text {st }} \\
\text { Prob. }\end{array}$ & $\begin{array}{c}2^{\text {nd }} \\
\text { Prob. }\end{array}$ \\
\hline 1 & Vul & 0.690 & 0.000 & - \\
2 & NPF & 0.798 & 0.000 & - \\
3 & LIK & 0.090 & 0.000 & - \\
4 & LFIN & 0.934 & 0.000 & - \\
5 & LSIZE & 0.914 & 0.000 & - \\
6 & RATE & 0.614 & 0.000 & - \\
7 & INF & 0.221 & 0.000 & - \\
8 & USD & 0.158 & 0.000 & - \\
9 & GROWTH & 0.012 & 0.552 & - \\
\hline
\end{tabular}

\section{Cointegration Test Results}

Table 4 presents the cointegration using the Bound Test. The results showed that there is a short-run to balance a long-term on these variables.

Table 4. Bound Test

\begin{tabular}{lcccc}
\hline \multicolumn{1}{r}{ Test Statistical } & Value & Significant. & $\mathrm{I}(0)$ & $\mathrm{I}(1)$ \\
\hline F-statistic & 5.122 & $10 \%$ & 1.85 & 2.85 \\
$\mathrm{~K}$ & 8 & $5 \%$ & 2.11 & 3.15 \\
& & $2.5 \%$ & 2.33 & 3.42 \\
& & $1 \%$ & 2.62 & 3.77 \\
\hline
\end{tabular}

\section{Short and long-term coefficients of ARDL method estimation}

Table 5 shows the short-term relationship based on the ARDL.

Table 5. ARDL Short-Term Estimation Results

\begin{tabular}{lrrrl}
\hline \multicolumn{1}{r}{ Variable } & Coefficient & \multicolumn{1}{c}{ Std. Error } & \multicolumn{1}{c}{ T-Statistic } & \multicolumn{1}{c}{ Prob. ${ }^{*}$} \\
\hline VUL(-1) & 0.391 & 0.145 & 2.709 & $0.011^{*}$ \\
VUL(-2) & -0.099 & 0.150 & -0.665 & 0.512 \\
VUL(-3) & -0.090 & 0.137 & -0.659 & 0.515 \\
VUL(-4) & -0.280 & 0.111 & -2.524 & $0.017^{*}$ \\
NPF & -1.114 & 0.481 & -2.316 & $0.028^{*}$ \\
NPF(-1) & -1.285 & 0.511 & -2.515 & $0.017^{*}$ \\
NPF(-2) & -0.535 & 0.556 & -0.962 & 0.344 \\
NPF(-3) & -0.454 & 0.545 & -0.834 & 0.412 \\
NPF(-4) & -0.835 & 0.536 & -1.558 & 0.131 \\
LIK & 0.079 & 0.021 & 3.741 & $0.000^{*}$ \\
LFIN & -11.580 & 5.180 & -2.235 & $0.033^{*}$ \\
LSIZE & -17.477 & 7.272 & -2.403 & $0.023^{*}$ \\
\multicolumn{1}{c}{-} & 17.585 & 8.120 & 2.166 & $0.039^{*}$
\end{tabular}




\begin{tabular}{lrrrl}
\hline \multicolumn{1}{c}{ Variable } & Coefficient & Std. Error & T-Statistic & Prob.* $^{*}$ \\
\hline LSIZE( 1) & & & & \\
LSIZE(-2) & 8.458 & 8.069 & 1.048 & 0.304 \\
LSIZE(-3) & -20.103 & 7.730 & -2.601 & $0.014^{*}$ \\
LSIZE(-4) & 16.677 & 6.651 & 2.507 & $0.018^{*}$ \\
RATE & 0.700 & 0.484 & 1.449 & 0.159 \\
RATE(-1) & -3.027 & 0.660 & -4.586 & $0.000^{*}$ \\
RATE(-2) & 1.772 & 0.773 & 2.292 & $0.029^{*}$ \\
RATE(-3) & 0.407 & 0.708 & 0.575 & 0.570 \\
RATE(-4) & 0.859 & 0.543 & 1.582 & 0.125 \\
INF & 0.494 & 0.242 & 2.040 & 0.051 \\
INF(-1) & -0.631 & 0.251 & -2.519 & $0.018^{*}$ \\
INF(-2) & 0.511 & 0.241 & 2.117 & $0.043^{*}$ \\
INF(-3) & -0.203 & 0.189 & -1.069 & 0.294 \\
USD & 8.022 & 5.221 & 1.537 & 0.136 \\
USD(-1) & 6.935 & 5.431 & 1.277 & 0.212 \\
USD(-2) & -11.130 & 5.112 & -2.177 & $0.038^{*}$ \\
USD(-3) & 17.557 & 5.719 & 3.070 & $0.007^{*}$ \\
USD(-4) & 11.428 & 6.187 & 1.847 & 0.075 \\
GROWTH & 0.988 & 3.026 & 0.326 & 0.747 \\
GROWTH(-1) & -2.335 & 4.731 & -0.493 & 0.626 \\
GROWTH(-2) & 0.592 & 4.413 & 0.134 & 0.894 \\
GROWTH(-3) & 4.146 & 2.678 & 1.548 & 0.133 \\
C & -81.081 & 70.221 & -1.155 & 0.258 \\
R-squared & 0.977 & Akaike info criterion & 1.862 \\
Adjusted R-squared & 0.949 & Schwarz criterion & 3.053 \\
F-statistic & 35.630 & Prob(F-statistic) & & 0.000 \\
\hline
\end{tabular}

Description: * Significance level below 0.05

The exceptional ARDL version with the most acceptable lag mixture was decided primarily based on the Akaike Info Criterion. Therefore, the best model for this study is ARDL (4, 4, 0, 0, 4, 4, 3, 4, 3). The R-Squared Adjusted value and the R-Bar-Squared are relatively high with an average of 0.977 and 0.949. Meanwhile, the R-Squared Adjusted value of 0.949 shows that $94.90 \%$ of the vulnerability is explained by the independent variables. This makes this study to be properly analyzed.

The table shows that VUL(-1), VUL(-4), NPF, NPF(-1), LIK, LFIN, LSIZE, LSIZE(1), $\operatorname{LSIZE}(-3), \operatorname{LSIZE}(-4), \operatorname{RATE}(-1), \operatorname{RATE}(-2), \operatorname{INF}(-1), \operatorname{INF}(-2), \operatorname{USD}(-2)$, and USD(-3) have probability values less than 0.05 . This means that at the $95 \%$ confidence level independent variables significantly affects banks vulnerability. Table 6 shows the long-term relationship based on the ARDL method.

Table 6. ARDL Long-Term Estimation Results

\begin{tabular}{lrrrr}
\hline \multicolumn{1}{c}{ Variable } & \multicolumn{1}{c}{ Coefficient } & Std. Error & T-Statistic & Prob.* \\
\hline NPF & -3.916 & 0.655 & -5.979 & 0.000 \\
LIK & 0.073 & 0.021 & 3.542 & 0.001 \\
LFIN & -10.738 & 4.421 & -2.429 & 0.022 \\
LSIZE & 4.765 & 3.586 & 1.329 & 0.195 \\
RATE & 0.661 & 0.219 & 3.022 & 0.005 \\
INF & 0.158 & 0.277 & 0.571 & 0.573 \\
USD & 30.424 & 3.728 & 8.161 & 0.000 \\
GROWTH & 3.145 & 2.217 & 1.418 & 0.167 \\
C & -75.180 & 65.424 & -1.149 & 0.260 \\
EC $=$ VUL - $(-3.916 *$ NPF $+0.073 *$ LIK - $10.738 *$ LFIN + 4.765*LSIZE +0.661*RATE \\
$\quad+0.158 *$ INF + 30.424*USD + 3.144*GROWTH 75.179) \\
\hline
\end{tabular}

Note: The significance level is below 0.05 
The long-term estimation showed that the NPF, LIK, LFIN, RATE, and USD significantly affects Islamic banking VUL with 5\%, while the LSIZE, INF, and GROWTH failed to influence it because they have a probability value greater than 0.05 (5\%). These results indicated that the USD variable has the most considerable coefficient value. This means that the exchange rate is the dominant factor that affects the Islamic banking vulnerability in Indonesia. Meanwhile, the increase in the exchange rate by $1 \%$ tends to develop the financial instability by $30.42 \%$. The following is the equation formed from the table.

$$
\begin{aligned}
\text { VUL }= & -75.180-3.916 * \mathrm{NPF}+0.073 * \mathrm{LIK}-10.738 * \mathrm{LFIN}+4.765 * \mathrm{LSIZE}+0.661 * \mathrm{RATE} \\
& +0.158 * \mathrm{INF}+30.424 * \mathrm{USD}+3.145 * \mathrm{GROWTH}
\end{aligned}
$$

These results showed that NPF significantly affects the Islamic bank's vulnerability in Indonesia. Also, the short-term estimation indicated that NPF and NPF(-1) have a significant effect on financial instability. This means that the increase in the credit risk disbursed tends to make it have a relationship with the lower bank vulnerability. However, credit with risk means potential for failure in large returns from creditors. Failure to repay these funds tends to increase banks' vulnerability because it affects their operational activities. These results are in line with the previous studies that showed the relationship between credit risk and financial instability(Ghenimi et al., 2017; Trabelsi \& Trad, 2017).

The long-term estimation indicated that liquidity risk significantly affects Islamic bank vulnerability in Indonesia. Also, the short-term results showed that LIK substantially influences financial instability. Banks tend to face LIK if they do not liquidate their assets at a fair price because this risk is not eradicated on time. Meanwhile, the low selling prices of investments lead to significant losses and decreases in revenue. These results are in line with previous studies that liquidity risk significantly influences bank stability (Ali \& Puah, 2018, Trabelsi \& Trad, 2017; Fatoni \& Sidiq, 2019; Ghenimi et al., 2017; Amara \& Mabrouki, 2019).

Also, the long-term estimation indicated that Financing significantly affects Islamic bank vulnerability in Indonesia. The short-term results showed that LFIN has a substantial influence on vulnerability. Financing in the form of a credit to individuals and corporations for various purposes of consumption, investment, working capital, and others affects the natural sector movement and economic growth. The increase in the funds disbursed tends to high the bank's ability to provide loans. This means that the influence of an increased income irrespectively develops bank profits. Therefore, more funds will be channeled if this ratio increases within a specific limit. Adequate distribution of financing tends to boost bank profits and decrease its vulnerability. These results are in line with previous studies that LFIN significantly affects bank stability (A1-Khouri \& Arouri, 2016; Ghenimi et al., 2017; Ali \& Puah, 2018). 
The long-term estimation indicated that LSIZE has no significant influence on the Islamic bank vulnerability in Indonesia. Also, the short-term results showed that LSIZE, LSIZE(-1), LSIZE(-3), LSIZE(-4) significantly affect financial instability. Companies with a more considerable influence increase in profitability and value because they are relatively stable. Therefore, size development tends to easily allow an organization to obtain funds to increase its value. These results are in line with previous studies that total assets significantly influences bank vulnerability (Trabelsi \& Trad, 2017; Ghenimi et al., 2017; Amara \& Mabrouki, 2019; Ozili, 2018).

Moreover, the long-term estimation showed that BI Rate significantly affects Islamic bank vulnerability in Indonesia. The short-term results indicated that RATE(-1) and RATE(-2) significantly influences financial instability. The bank is a financial institution that collects funds from the public in form of savings, demand, and time deposits. These deposits have a cost that needs to be replaced in the form of a profit-sharing bonus. Meanwhile, the interest rate is a systemic monetary instrument that influences the determination of bank deposits. The profitsharing that needs to be paid to creditors increases if there is a development in the SBI. However, the increase in fees causes the banks to pay their obligations to creditors in high financial instability. These results are in line with the study of Diaconu and Oanea (2014) also Sevim, Oztekin, Bali, Gumus, and Guresen (2014).

The long-term estimation showed that inflation has no significant effect on Islamic bank vulnerability in Indonesia. Also, the short-term results indicated that INF(-1) and INF(-2) significantly affect financial instability. This indicates that the debtor is benefitted if inflation is higher than what is expected. Moreover, the creditor is harmed because the debtor pays the financing with a smaller amount of money, and the profits obtained are not proportional to the costs that need to be paid. This enables banks to pay obligations to creditors which directly leads to an increase in vulnerability. These results are in line with the study of Trabelsi and Trad (2017), Ghenimi et al. (2017), and Trad et al. (2017).

Furthermore, the Rupiah's exchange rate against the US Dollar is essential in the international economy. The long-term results showed that USD significantly affects the Islamic bank vulnerability in Indonesia. Also, the short-term estimation indicated that USD (-2) and USD (-3) significantly affect financial instability. These results showed that the LKURS variable has the most significant coefficient value. This means the exchange rate is the dominant factor that affects the Islamic banks' vulnerability in Indonesia. Therefore, an increase in the exchange rate by $1 \%$ tends to develop financial instability by $30.42 \%$. The exchange rate influences Islamic banking because some deposits are denominated in US Dollars and not only in Rupiah. Meanwhile, the Rupiah is called depreciation and appreciation 
if it weakens and strengthens the USD respectively. This is because the amount of Rupiah that needs to be returned increases if its exchange rate cuts. These results are in line with the study of Srairi (2013), Rajhi and Hassairi (2013), and Ariefianto and Soepomo (2013) that the exchange rate positively affects bank vulnerability.

The long-term estimation showed that GROWTH does not affect Islamic bank vulnerability in Indonesia. These results indicated that economic growth failed to directly reduce financial instability while it increases. For instance, a country's economic growth does not encourage banks to channel credit while it advances in 2014-2020. Also, in the 2008-2009 crisis, the economic activity failed to reduce Islamic bank vulnerability despite its development in Indonesia. These results are not in line with the study of Fatoni and Sidiq (2019) and Abdul, Saba, and Muhammad (2017) that economic growth significantly affects financial instability.

\section{CONCLUSION}

In Indonesia, Islamic bank vulnerability is influenced by Non-Performing Financing, Liquidity Risk, Financing, Bank Size, Interest, Rupiah Exchange Rate, and Inflation. This study results showed that Economic Growth is the only variable that failed to affect financial instability. Moreover, the Lags including VUL(-1) and VUL(-4) affect Islamic bank vulnerability.

There tend to be a continuous and synergized cooperation between the government, the Central Bank, and society to accelerate market share because this study provides an overview of financial condition and activities. However, Islamic banks need to always pay attention to internal and external factors especially the profit-sharing-based that affect their stability. Also, this financial institution has to perform stricter monitoring and assistance to avoid the risk of bad loans and reduce operational costs.

Further study is needed to consider using the banking condition, stress, and stability Index for the vulnerability measurement. Also, it has to use macroeconomic variables including the IDX composite, foreign exchange reserves, gold prices, profit sharing equivalents, and investment levels. In conclusion, all countries that operate an Islamic banking system are recommended to participate in the study.

\section{BIBLIOGRAPHY}

Abdul, R., Saba, Y., \& Muhammad, K. (2017). Does Islamic Banking Really Strengthen Financial Stability? Empirical Evidence from Pakistan. International Journal of Islamic and Middle Eastern Finance and Management, 10(2), 130-148. https://doi. org/10.1108/IMEFM-11-2015-0137. 
Al-Khouri, R., \& Arouri, H. (2016). The Simultaneous Estimation of Credit Growth, Valuation, and Stability of the Gulf Cooperation Council Banking Industry. Economic Systems, 40(3), 499-518. https://doi.org/10.1016/j.ecosys.2015.12.005.

Ali, M., \& Puah, C. H. (2018). Does Bank Size and Funding Risk Effect Banks' Stability? A Lesson from Pakistan. Global Business Review, 19(5), 1166-1186. https://doi.org/10.1177/0972150918788745.

Ali, M., \& Puah, C. H. (2019). The Internal Determinants of Bank Profitability and Stability. Management Research Review. https://doi.org/10.1108/MRR-04-2017-0103.

Ali, M., Sohail, A., Khan, L., \& Puah, C. H. (2019). Exploring the Role of Risk and Corruption on Bank Stability: Evidence from Pakistan. Journal of Money Laundering Control, 22(2), 270-288. https://doi.org/10.1108/JMLC-03-2018-0019.

Amara, T., \& Mabrouki, M. (2019). The Impact of Liquidity and Credit Risks on the Bank Stability. Journal of Smart Economic Growth, 4(2), 97-116.

Ariefianto, M. D., \& Soepomo, S. (2013). Risk Taking Behavior of Indonesian Banks: Analysis on the Impact of Deposit Insurance Corporation Establishment. Bulletin of Monetary Economics and Banking, 15(3), 1-20. https://doi.org/10.21098/bemp.v15i3.425.

Beck, T., Demirgüç-Kunt, A., \& Merrouche, O. (2013). Islamic vs. Conventional Banking: Business Model, Efficiency and Stability. Journal of Banking \& Finance, 37(2), 433-447. https://doi.org/10.1016/j.jbankfin.2012.09.016.

Bernanke, B. S. (2013). Monitoring the Financial System. 49th Annual Conference on Bank Structure and Competition. Sponsored by the Federal Reserve Bank of Chicago, Chicago, Illinois, May 10, 2013.

Bundesbank, D. (2003). Report on the Stability of the German Financial System. In Monthly Report (Vol. 55).

Chant, J. (2003). Financial Stability As a Policy Goal. Essays on Financial Stability, 95.

Cihak, M., \& Hesse, H. (2010). Islamic Banks and Financial Stability: An Empirical Analysis. Journal of Financial Services Research, 38(2-3), 95-113. https://doi.org/10.1007/ s10693-010-0089-0.

Crockett, A. (1996). The Theory and Practice of Financial Stability. De Economist, 144(4), 531-568. https://doi.org/10.1007/BF01371939.

Demirgüç-Kunt, A., Detragiache, E., \& Tressel, T. (2008). Banking on the Principles: Compliance with Basel Core Principles and Bank Soundness. Journal of Financial Intermediation, 17(4), 511-542.https://doi.org/10.1016/j.jfi.2007.10.003.

Diaconu, R. I., \& Oanea, D. C. (2014). The Main Determinants of Bank's Stability. Evidence from Romanian Banking Sector. Procedia Economics and Finance, 16, 329-335.

Diamond, D. W., \& Dybvig, P. H. (1983). Bank Runs, Deposit Insurance, and Liquidity. Journal of Political Economy, 91(3), 401-419. https://doi.org/10.1086/261155.

Fakhri, K., \& Khemaies, B. (2017). Regulatory Capital and Stability of Islamic and Conventional Banks. International Journal of Islamic and Middle Eastern Finance and Management, 10(3), 312-330. https://doi.org/10.1108/IMEFM-06-2016-0079. 
Fatoni, A., \& Sidiq, S. (2019). Analisis Perbandingan Stabilitas Sistem Perbankan Syariah dan Konvensional di Indonesia. Ekspansi: Jurnal Ekonomi, Keuangan, Perbankan dan Akuntansi, 11(2), 179-198.

Ghenimi, A., Chaibi, H., \& Omri, M. A. B. (2017). The Effects of Liquidity Risk and Credit Risk on Bank Stability: Evidence from the MENA Region. Borsa Istanbul Review, 17(4), 238-248. https://doi.org/10.1016/j.bir.2017.05.002.

Gujarati, D. N. (2011). Econometrics by Example (Vol. 1). New York: Palgrave Macmillan.

Harzevili, S. K., \& Chirani, E. (2016). The Relationship between Credit Risk and the Performance of Banks. International Journal of Advanced Biotechnology and Research, 7, 1712-1723.

Kaufmann, D., Kraay, A., \& Mastruzzi, M. (2013). Governance Matters IV: Governance Indicators for 1996-2004. World Bank Policy Research Working Paper. https://doi.org/10.1596/1813-9450-3630.

Khasawneh, A. Y. (2016). Vulnerability and Profitability of MENA Banking System: Islamic versus Commercial Banks. International Journal of Islamic and Middle Eastern Finance and Management, 9(4), 454-473. https://doi.org/10.1108/IMEFM-09-20150106.

Mishkin, F. S. (1999). Global Financial Instability: Framework, Events, Issues. Journal of Economic Perspectives, 13(4),3-20. https://doi.org/10.1257/jep.13.4.3.

Mirza, N., Rahat, B., \& Reddy, K. (2015). Business Dynamics, Efficiency, Asset Quality and Stability: The Case of Financial Intermediaries in Pakistan. Economic Modelling, 46(C), 358-363. https://doi.org/10.1016/j.econmod.2015.02.006.

Ozili, P. K. (2018). Banking Stability Determinants in Africa. International Journal of Managerial Finance, 14(4), 462-483. https://doi.org/10.1108/IJMF-01-2018-0007.

Pambuko, Z. B., Ichsan, N., \& Anto, M. H. (2018). Islamic Banks' Financial Stability and Its Determinants: a Comparison Study With Conventional Banks in Indonesia. Iqtishadia J. Kaji. Ekon. dan Bisnis Islam, 11(2), 371-390. https://doi.org/10.21043/iqtishadia. v11i2.3346.

Rajhi, W., \& Hassairi, S. A. (2013). Islamic Banks and Financial Stability: a Comparative Empirical Analysis between MENA and Southeast Asian Countries. Région et Développement, 37(1), 1-31.https://doi.org/10.2139/ssrn.2010126.

Rashid, A., Yousaf, S., \& Khaleequzzaman, M. (2017). Does Islamic Banking Really Strengthen Financial Stability? Empirical Evidence from Pakistan. International Journal of Islamic and Middle Eastern Finance and Management, 10(2), 130-148. https://doi.org/10.1108/IMEFM-11-2015-0137.

Rusydiana, A., Rani, L., \& Hasib, F. (2019). Manakah Indikator Terpenting Stabilitas Sistem Keuangan?: Perspektif Makroprudensial. Jurnal Ekonomi Pembangunan, 27, 25-42. https://doi.org/10.14203/JEP.27.1.2019.25-42.

Schinasi, G. J. (2007). Preserving Financial Stability. International Monetary Fund. https://doi.org/10.5089/9781589065024.051. 
Sevim, C., Oztekin, A., Bali, O., Gumus, S., \& Guresen, E. (2014). Developing an Early Warning System to Predict Currency Crises. European Journal of Operational Research, 237(3), 1095-1104. https://doi.org/10.1016/j.ejor.2014.02.047.

Simorangkir, I. (2014). Pengantar Kebanksentralan: Teori dan Praktik di Indonesia. Jakarta: Rajawali Pers.

Srairi, S. (2013). Ownership Structure and Risk-taking Behaviour in Conventional and Islamic Banks: Evidence for MENA Countries. Borsa Istanbul Review, 13(4), 115-127. https://doi.org/10.1016/j.bir.2013.10.010.

Statistik Perbankan Syariah. (2021). Retrieved January 12, 2021, from Otoritas Jasa Keuangan. 2019 website: https://www.ojk.go.id/id/kanal/syariah/data-danstatistik/statistik-perbankan-syariah/Default.aspx.

Trabelsi, M. A., \& Trad, N. (2017). Profitability and Risk in Interest-Free Banking Industries: A Dynamic Panel Data Analysis. International Journal of Islamic and Middle Eastern Finance and Management, 10(4), 454-469. https://doi.org/10.1108/IMEFM-05 20160070 .

Trad, N., Rachdi, H., Hakimi, A., \& Guesmi, K. (2017). Banking Stability in the MENA Region During the Global Financial Crisis and the European Sovereign Debt Debacle. The Journal of Risk Finance, 18(4), 381-397. https://doi.org/10.1108/JRF-10-2016-0134. 